\title{
Betting exclusively by private labels: could it have negative consequences for retailers?
}

\section{La apuesta exclusiva for la marca de distribuidor: ¿puede tener consecuencias negativas para el minorista?}

\author{
José Luis Ruiz-Real and Juan Carlos Gázquez-Abad \\ School of Economics and Business, University of Almeria, \\ Agrifood Campus of International Excellence ceiA3, Almeria, Spain \\ Irene Esteban-Millat \\ Open University of Catalonia, Barcelona, Spain, and \\ Francisco J. Martínez-López \\ University of Granada, Granada, Spain
}

\begin{abstract}
Purpose - The authors analyze the relationship between different consumer attitudinal variables and a number of variables related to consumer perception of the store and purchasing behavior, in assortments composed exclusively of private labels (PLs).

Design/methodology/approach - The authors developed an experiment based on an online survey to test the hypotheses formulated. The model's causal relationships are established using structural equations.

Findings - The image of stores that only offer their own brand is mainly configured by price consciousness and the attitude toward the private label. The private label purchase intention is strongly influenced by the store image and a favorable attitude toward the brand, and loyalty strategies should be aimed at securing a clear perception of providing real value.

Practical implications - For retailers who only offer their own brands, an assortment with pricecompetitive PLs is key to the strategy of differentiating them from other retailers. It is reasonable to assume that, if retailers have a favorable image, customers transfer this brand value to their PLs and trust them.

(C) José Luis Ruiz Real, Juan Carlos Gázquez-Abad, Irene Esteban-Millat and Francisco J. MartínezLópez. Published in Spanish Journal of Marketing - ESIC. Published by Emerald Publishing Limited. This article is published under the Creative Commons Attribution (CC BY 4.0) licence. Anyone may reproduce, distribute, translate and create derivative works of this article (for both commercial and noncommercial purposes), subject to full attribution to the original publication and authors. The full terms of this licence may be seen at http://creativecommons.org/licences/by/4.0/legalcode

This work has been funded by the Fundación Ramón Areces.
\end{abstract}

Received 8 April 2016 Revised 7 October 2016 Accepted 29 December 2016 
Customer loyalty strategies of these retailers should be aimed at ensuring that consumers clearly perceive that their assortment provides real value and that, although it is limited in terms of number of brands, it can meet all their needs.

Originality/value - This research represents a significant contribution to brand management literature because, includes, together with loyalty to the store, its image and the PL purchase intention as consumer response variables. Another differentiating feature is the methodology used. Estimation of the structural equation model permits the simultaneous estimation of the relationships between the variables.

Keywords Retailing, Private label, Image, Assortment, National brand

Paper type Research paper

\section{Resumen}

Objetivos - Analizamos la relación entre diferentes variables actitudinales de los consumidores y un número de variables relativas a la percepción de los consumidores con respecto al establecimiento y el comportamiento de compra, todo ello en surtidos compuestos exclusivamente por marcas de distribuidor.

Metodología - Desarrollamos un experimento online, basado en una encuesta, para testar las hipótesis planteadas. Utilizamos ecuaciones estructurales para determiner las relaciones causales del modelo.

Resultados - La imagen de los establecimientos que ofrecen exclusivamente su propia marca se configura, principalmente, por la conciencia de precio y por la actitud de los consumidores hacia la marca privada. La intención de compra de la marca de distribuidor está fuertemente influenciada por la imagen del establecimiento y por una actitud favorable hacia dicha marca, por lo que las estrategias de fidelización de clientes deberían estar orientadas a asegurar una clara percepción de proporcionar valor real a los consumidores.

Implicaciones prácticas - Para los minoristas que ofertan exclusivamente sus propias marcas, un surtido con marcas de distribuidor muy competitivas en precio es fundamental en su estrategia de diferenciación de sus competidores. Además, es razonable suponer que si los minoristas cuentan con una imagen favorable, los consumidores trasladarán este valor de marca a sus propias marcas propias y confiarán en ellas. Las estrategias de fidelización de este tipo de minoristas deberían ir enfocadas a asegurarse de que los consumidores perciben claramente el valor real que aporta su surtido y que, aunque limitado en términos de número de marcas y alternativas, les permite cubrir todas sus necesidades.

Originalidad/valor - Esta investigación supone una significativa contribución a la literatura sobre gestión de marcas al incluir, conjuntamente con la lealtad al establecimiento, su imagen y la intención de compra de la marca de distribuidor como variables respuesta del consumidor. Otro elemento diferenciador es la metodología empleada, ya que la estimación del modelo de ecuaciones estructurales permite la estimación simultánea de las relaciones entre las distintas variables.

Palabras clave - Marca privada, Minoristas, Diversidad, Marca nacional, Imagen

Tipo de artículo - Trabajo de investigación

\section{Introduction}

Retail distribution sector is clearly important in Spain's economy. According to the country's Annual Trade Survey, carried out by its National Statistics Institute in 2013, wholesale and retail contributed 12.3 per cent to the gross added value of the Spanish economy and accounted for 10.9 per cent of the workers in the social security system. In 2014, the estimated turnover of retail trade stood at $€ 206,776,441$, achieving the greatest increase in recent years. According to figures from consultants Kantar Worldpanel (2016), Mercadona is, by far, Spain's leading supermarket chain, with a 22.3 per cent share of retail food sales in 2015, followed by Carrefour (8.6 per cent), DIA (8.2 per cent), Grupo Eroski (5.8 per cent) and Lidl and Auchan (3.8 per cent). Also, according to the same report, the ten leading distribution groups in Spain encompass 52.9 per cent of sales of fast-moving consumer goods. This is why any decisions made by sector companies with regard to their brand portfolio are of particular importance.

The market share of private labels (PLs) in Spain reached 42 per cent by value and 49.7 per cent by volume in 2014 (IRI, 2015). Large supermarkets increased their share to 48 per cent, with Mercadona leading the market, followed by Carrefour and Eroski. Spain's top 
ten retailers accounted for 84 per cent of the market share. Nevertheless, noteworthy is the strong progress made by retail formats such as "hard discount" stores and "category killers", some of which can on occasion sell only their own PLs.

The changes arising in Spain in food-based retail distribution from the 1970s onwards have been highly significant and have been accentuated by the recent economic recession, which has caused a shift in consumer priorities and behavior. One of the most important changes has been the consolidation of PLs, something that has caused far-reaching changes in the makeup of companies' assortments. The increased market share of PLs has become generalized worldwide, with a special impact upon the consumer packaged goods sector (Ailawadi et al., 2008). Development of PLs has been boosted by the organization of food distribution through chains of retailers, mainly in Europe and other developed economies. Although the start of this great growth coincided with the economic crisis, companies have been able to develop strategies that allow them to take advantage of the opportunity to develop and consolidate their PLs. These own brands have also noticeably improved their positioning and image amongst consumers, thanks to a greater on-shelf presence and significant investment in communication by retailers. In 2014, 13 per cent of PLs sold in Spain were on sale, a 4 per cent increase over the previous year, largely owing to Mercadona's firm backing for its own brand, which led it to using the price promotion strategy for the first time (IRI, 2015). All this has meant that PLs are often considered as an optimal alternative to national brands (Lamey et al., 2012), in that they offer good value for money.

The literature provides a variety of definitions for private labels. Serra and Puelles (1993) refer to them as those that, disassociated from the brand of the manufacturer producing them, are sold by a specific distributor that gives them its own or another different name, with it being this distributor that carries out the marketing work. Casares and Rebollo (1996) state that private labels refer to those products made by a specific industrial concern that are offered to consumers under the name or brand of the distributor or retailer, which carries out all the marketing work associated therewith. For Puelles and Puelles (2003), private labels are brands whose legal title is held by the distributor and whose production is usually entrusted to an established manufacturer. In their production, the manufacturer follows the specifications set by the retailer with regard to composition, quality, design, packaging, etc. The American Marketing Association (AMA) refers to private labels as a brand that is owned and controlled by the product's distributor, such as the retailer or wholesaler, rather than by its manufacturer. The term applies not only to the brand itself but also encompasses the product and its content. There is a wide variety of names used to describe these brands (Fernández and Reinares, 1998; Galván, 2007), including: private labels, private brands, store brands, own labels, own brands, retailer's brands and home brands.

Retailers may launch PLs developing different market strategies and seeking different competitive positionings by means of different customer value propositions (GonzálezBenito and Martos-Partal, 2010). Said value propositions may vary significantly in terms of coverage of product categories, price, objective quality, shelf positioning, promotional efforts, etc., meaning that consumer perception of the benefits and risks of PLs varies greatly from one to the other. The classification of PLs most commonly used, in both academic and professional circles, is that proposed by Kumar and Steenkamp (2007), who point to the existence of four types of private labels with regard to customer value propositions: generics, copycats, premium store brands and value innovators. This gives rise to different types of PLs. The Alliance Consulting Group (2014) establishes a classification of the different private labels based on their features, distinguishing between the traditional private label, retailer brand, retailer brand with value position, retailer brand with premium position, umbrella brand, category brand, store brand and orphan brand. 
SJME

22,2

The market features two opposing kinds of demand or trends: the demand for increasingly differentiated products and that for basic products, through which the consumer basically considers price (Berné, 2006). The demand for basic products, which has grown significantly in recent years and which has increased market share following the economic crisis, mainly translates into PLs or low-cost brands. With such products, retailers seek to obtain a better return from their assortment (Cruz, 1999; Méndez, et al., 2008) and to boost customer loyalty (Oubiña et al., 2006). It must be borne in mind that consumers seek greater efficiency when purchasing these brands: in other words, lower prices, similar perceived quality to national brands and confidence in their choice. Nevertheless, these opposing trends also affect many products and intermediary brands, which, taken together, make up the retailer's portfolio. Price is not the only determining factor in a consumer's decision-making process, which is also affected by those such as convenience and good value for money.

The expansion of PLs has caused structural changes that affect the sector as a whole: retailers, manufacturers and consumers. Retailers have embarked upon a clear strategy of market segmentation via their PLs, in close accordance with price, product category and the benefits sought by consumers (Castelló, 2012), originating a number of scenarios in which to implement the wide variety of PLs. So it is that PLs have expanded beyond market segments based almost exclusively on price, to position themselves as brands that offer unbeatable value for money and are attractive to a new kind of consumer who has developed a keen consciousness of pricing and value. Today, retail management cannot simply rely on offering very broad assortments or on designing a sales strategy based on a single brand, the in-house one, at very aggressive prices. They must offer customers an assortment that, irrespective of its size and composition, offers real value to customers and an appropriate response to their needs (Miranda and Joshi, 2003). The main function of the retailer must be to help secure a significant improvement in the efficiency of the consumer's purchasing process, which will help give the former a competitive edge and specific commercial differentiation (Berné, 2006). As a result, a new concept in stores is emerging that aims to attract a greater number of consumers toward its PLs, offering both low prices and good value for money. In recent years, Spain has seen the opening of retail establishments with very wide assortments but using a model similar to that of cash and carries (e.g. Costco and Dealz).

Within this context of the growing presence of PLs, many companies have implemented strategies of reducing their assortment, chiefly by means of withdrawing a great number of national brands and giving more prominence to their own labels (Henderson and Mihas, 2000; Ailawadi and Harlam, 2004). It is known that there are different assortment reduction strategies, ranging from those that eliminate only some products from different brands, to other, more radical, ones that choose to remove all of a specific brand's products within an assortment category (Sloot and Verhoef, 2008), which is also known as "brand delisting". Looking at the compilation made by Gázquez-Abad et al. (2015) of retailers implementing strategies of delisting brands from their assortment, we can quote the examples of Wal-Mart (which cut its overall assortment by 30 per cent in the UK and 7.6 per cent in the USA), Dutch food chain Edah, Britain's Asda and Germany's Edeka and Metro, among others. The Carrefour group introduced a product category optimization program, reducing the size of its assortment by 15 per cent (Berg and Queck, 2010). In Spain, best known is the case of Mercadona, which, in December 2008, removed from its shelves almost 800 brands from different manufacturers, some of which are leaders in their product category (e.g. Nestlé, Calvo and Pascual). Nevertheless, many of these retailers (including Mercadona) were subsequently forced to reintroduce some of these previously withdrawn brands to prevent consumer boycotts and the harm that the decision was causing to their own image (Sloot and Verhoef, 2011). 
Therefore, it is not just a simple decision of delisting brands from the assortment, without further ado. Withdrawing certain national brands may harm the store's image, as consumers regard its assortment as incomplete, either because it does not include most available brands (Pepe et al., 2012) or because it does not include leading ones (Sloot and Verhoef, 2008). Some papers suggest that retailers should seek a proper balance between PLs and national brands (González-Benito and Martos-Partal, 2010).

So, what are retailers to do? Should they indeed seek such a balance between national brands and their own labels? Or should they, by way of contrast, opt for assortments without national brands? Obviously, the decision taken by the retailer in this regard is a vital one not only from the viewpoint of costs and sales margins but also from that of the image that consumers will develop of the company itself. The response to the above questions is therefore key to a retailer's success, as it will allow it to know which brands should comprise its assortment and which it can eliminate without hurting its image or its turnover figures.

With this in mind, an online experiment has been developed, with four product categories and a sample of 1,400 individuals belonging to a large Spanish consumer panel. The consumer response has been analyzed by means of estimating a structural equation model in which this is measured in terms of:

- store image;

- store switching intentions; and

- the private label purchase intention.

This research represents a significant contribution to brand management literature because, whilst it is true that some papers have analyzed the potential consequences for the retailer of using different assortment combinations (Sloot and Verhoef, 2008; Wiebach and Hildebrandt, 2002), such works kept at least one national brand alongside the PLs in the makeup of the assortments offered. Only the paper by Gázquez-Abad et al. (2015) considers, alongside two "mixed" alternatives (national brands with PLs), a scenario in which the retailer offered only its own brand. Nevertheless, these authors restricted themselves to comparing which option was most beneficial to the retailer based on an estimation of regression models that only included loyalty to the store as a dependent variable. Our study, unlike the aforementioned one, includes, together with loyalty to the store, its image and the PL purchase intention as consumer response variables. Another differentiating feature of our work is the methodology used. In this regard, estimation of the structural equation model permits the simultaneous estimation of the relationships between these three crucial aspects of retail management, as well as that between the set of attitudinal variables used (product category involvement, value consciousness, attitude toward the PL, value consciousness and perception of assortment variety) and the former.

The paper is structured as follows. Firstly, it reviews the literature to provide justification for the proposed hypotheses for the relationships between the variables considered. Next, it presents the methodology used for this research, as well as the results obtained. Finally, it presents the conclusions, with our proposals with regard to the implications arising for retail management.

\section{Review of the literature and development of hypotheses}

Figure 1 shows the framework for the research and depicts how the attitudinal variables (product category involvement, price consciousness, attitude toward the PL, value consciousness and perception of assortment variety) and the dependent variables (store image, 
SJME

22,2

\section{8}

Figure 1.

Model of proposed relationships

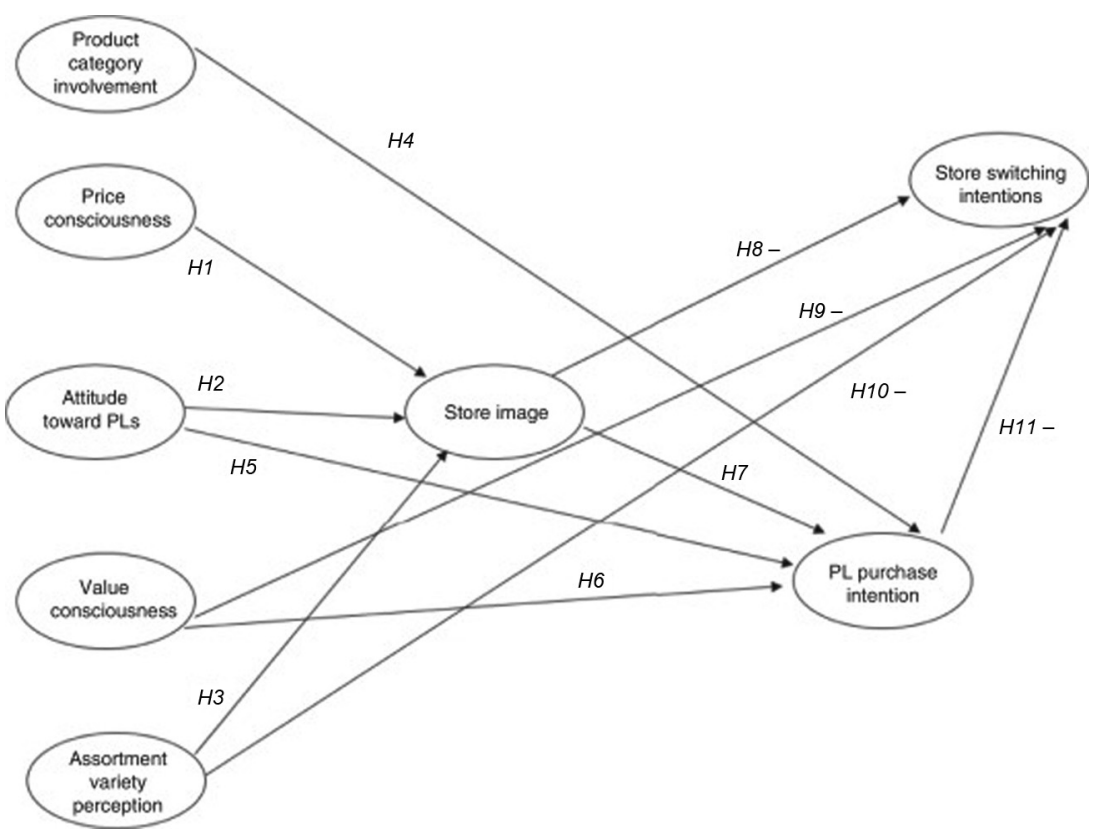

store switching intentions and PL purchase intention) are related, always within an environment of assortments made up exclusively of PLs, excluding national brands.

It then provides theoretical justification for the incorporation of the variables into the general model for the dependency relationship proposed between them, which subsequently translates into the formulation of the research's hypothesis. It starts with the variables that may have a direct influence on the store image, to continue with the background for store switching intentions and for the PL purchase intention.

\subsection{Store image}

Price is an indicator of the quality of products and of retailers (Darwar and Parker, 1994), such that large differences in prices between products and retailers may also lead to significant differences in the perception of quality (Richardson et al., 1994). In this way, price becomes an important factor in choosing brands and stores (Burton et al., 1998; Ailawadi et al., 2001; Sethuraman, 2006; Manzur et al., 2011; Méndez et al., 2008).

Price consciousness refers to the degree to which consumers focus exclusively on paying as little as possible (Lichtenstein et al., 1993). Those with high price consciousness prioritize low prices, excluding other factors when evaluating a brand or store, in that they believe them to be superfluous elements that do not provide them with real value. Based on the aforementioned evidence, we propose the following hypothesis:

H1. High price consciousness has a direct and positive impact on a store image.

The current economic crisis has helped give rise to growing generalized consumer interest in PLs (Lamey et al., 2007). In fact, there is now broad acceptance for PLs, which in some cases directly compete with national brands. Many retailers have taken strategic advantage of all 
of this to develop plans to expand their PLs (Gómez et al., 2011), even going so far as to introduce them into new product categories.

Numerous research papers have found a relationship between different variables associated with consumer behavior and store image, although only a few of them have analyzed the relationship between attitude and the perception of a store image and found it to be significant (Ajzen and Fishbein, 2004).

Given the above, we propose the following hypothesis:

H2. A favorable attitude toward private labels has a direct and positive impact on a store image.

Perception of assortment variety can be defined as the overall assessment made by a consumer of a specific set of products constituting a category within the store, to satisfy a specific consumer need (Bauer et al., 2012). Said perception may be influenced by numerous factors, such as the shelf/display implementation (Simonson, 1999) or the presence or absence of a favorite product (Broniarczyk et al., 1998).

The assortment is one of the key factors in a store image, helping to establish its personality and its success (Vázquez and Trespalacios, 2006). Although there is no consensus to the optimal size of the assortment, as both larger and smaller ones have pros and cons for consumers (Briesch et al., 2009; Chernev and Hamilton, 2009), it can be stated that large assortments have greater backing from, and tend to be beneficial for, consumers in which they offer more options (White and Hoffrage, 2009).

We therefore propose the following hypothesis:

H3. Perception of a wide variety in the assortment has a direct and positive impact on a store image.

\subsection{Private label purchase intention}

Consumer engagement with a product category tends to be defined as their long-term perception of the importance of a particular category, based on their inherent needs as a consumer, their values and their interests (De Wulf et al., 2001). The literature includes a number of papers regarding purchase intention as a key element in understanding consumer behavior in the decision-making process (Chakravarti and Janiszewski, 2003).

Product category involvement impacts the PL purchasing decision, although there is no clear sense of the relationship, as the literature provides conflicting results (Miquel $e t$ al., 2002; Berkowitz et al., 2005). This is probably because of the fact that the relationship between category involvement and PL purchase intention is dependent upon the type of product. Given that a large number of consumers currently perceive PL products as providing assurances and competing in quality with national brands (Fernández, 2010; Castelló, 2012), we suggest the following hypothesis:

H4. A high degree of product category involvement has a direct and positive impact on private label purchase intention.

Private labels have greatly improved their image in recent years, allowing consumers to develop a more favorable attitude toward them. For many consumers, PLs are no longer a secondary option or a second-class brand, but those are now regarded as a real alternative to national brands, competing with them on an equal footing.

Retailers have seen that they must provide real value to consumers with their assortments, leading them to make efforts to develop strategies delivering brand value (Pappu and Quester, 2006). It is in this regard that they are aware that they must boost their 
PLs, which are perceived of as having a quality similar to that of national brands, but at better prices, to thereby increase the purchase intention of said brand on the part of consumers.

In the literature, we find that a positive prior attitude toward a brand has a positive influence on the decision to purchase said brand (Kelmeci-Schneider, 2004; Zielke and Dobbelstein, 2007). In light of this, we propose the following hypothesis with regard to PLs:

H5. A favorable attitude toward private labels has a direct and positive impact on private label purchase intention.

Value consciousness is defined as the concern for paying less but subject to certain limitations with regard to product quality (Lichtenstein et al., 1993). Put another way, it involves securing optimal value for money.

Currently, and to a great extent owing to private labels' new position amongst consumers, the latter are more inclined to regard PLs as giving them an optimal balance between quality and price, leading them to consider them during their purchasing decisions. The literature points to a positive and significant relationship between value consciousness and a favorable attitude toward purchasing PLs, showing that these brands have achieved the value positioning sought by retailers (Garretson et al., 2002). This is confirmed by the existence of a positive and direct correlation between value consciousness and PL purchase intention (Jin and Suh, 2005), thus allowing us to formulate the following hypothesis:

H6. A high degree of value consciousness has a direct and positive impact on private label purchase intention.

The conveyance of trustworthiness by a store image will allay doubts about a product and increase a consumer's purchase intention (Semeijin et al., 2004; Siti et al., 2012). A favorable retailer image can reduce the consumer perception of risk, thereby adding value to its PLs (Agarwal and Teas, 2001).

Furthermore, the literature supports the existence of a positive relationship between a store image and the private label purchase intention of consumers (Liljander et al., 2009). Similarly, a strong, exclusive PL can boost loyalty toward a store and the PL purchase intention (Hu and Chuang, 2009). Based on this, we suggest the following hypothesis:

H7. A favorable store image has a direct and positive impact on private label purchase intention.

\subsection{Store switching intentions}

Martineau(1958) introduced the concept of store image, as a consumer's definition of a store based on its attributes, on both a functional and a psychological level. A store image therefore has a different positioning for every consumer. For its part, North et al. (2003) links a store's identity to its own image, which it considers an influencing factor in the initial stage of the consumer's purchasing decision-making process.

Store image is considered an important background factor in store loyalty, favoring repeat purchases and lessening store switching intentions (Wu et al., 2011). Someone with a favorable image of a store will develop a degree of loyalty commensurate with the favorable image he or she possesses (Johnson et al., 2001).

Based on this review of the literature, we propose the following hypothesis:

H8. A positive store image has a direct and negative impact on store switching intentions. 
Value-conscious consumers are characterized by paying special attention to the value for money they receive (Lichtenstein et al., 1990). Perceived value has a positive influence upon loyalty toward stores (Chen and Quester, 2006).

Nevertheless, we should highlight the fact that perceived value is a concept that is subjective in nature, arising from the comparative analysis by consumers of perceived benefits and the effort they must make (McDougall and Levesque, 2000). Loyalty is in this way defined from a twin standpoint: attitudinal and behavioral (Dick and Basu, 1994; Oliver, 1999). Given that changing store also entails cost and effort on the consumer's part, we propose the following hypothesis:

H9. Value consciousness has a direct and negative impact on store switching intentions.

The literature provides support for the fact that decisions on choosing stores display even more sensitivity toward changes in assortment variety than changes in prices (Briesch et al., 2009).

Numerous authors have found that assortment variety has a positive effect on store choice and loyalty thereto (Arnold et al., 1978; Finn and Louviere, 1996; Sirohi et al., 1998; Hoch et al., 1999; Baker et al., 2002; Verhoef et al., 2007). Wider assortments tend to be more attractive to consumers (Chernev, 2003; White and Hoffrage, 2009). So, we propose the following hypothesis:

H1O. Perception of a wide assortment variety has a direct and negative impact on store switching intentions.

When consumers buy a product from a company, they not only purchase the product itself but also receive a set of values from said company. In the specific case of PLs, ownership and control are in the hands of the retailer, which normally sells the products exclusively in its stores. In this way, PL products boost a retailer's image and can attract consumers (Gómez and Okazaki, 2007).

We find numerous papers arguing that a positive PL image encourages consumers to repurchase the same PL, in that it represents a series of values and, as a result, to return to the same store, discouraging store switching intentions (Allen and Rao, 2000; Corstjens and Lal, 2000; Rondán et al., 2006; San Martín, 2006; Martenson, 2007; Paiva et al., 2012).

In particular, Spanish consumers inclined toward PLs are characterized by their store loyalty (Martínez and Montaner, 2008). So, the following hypothesis is suggested:

H11. Private label purchase intent has a direct and negative impact on store switching intentions.

\section{Methodology}

To test the hypotheses formulated above, an online experiment was developed with a sample of 1,400 individuals belonging to an existing large consumer panel in Spain belonging to IRI. At the time of the study (March 2013), IRI had a consumer panel comprising 322,883 individuals aged between 24 and 65 responsible for their household purchases of food, cleaning and personal care products in supermarkets and hypermarkets, The IRI panel is statistically representative of the Spanish population, in terms of both sociodemographic variables (gender, age, income level, education level and family size) and geographical distribution.

Following IRI's recommendations of having a sample of at least 1,000 individuals (at least 35 people for each of the experiment's scenarios) to guarantee its representativeness, it 
SJME

22,2

\section{2}

was decided to use a sample of 1,400 individuals. These 1,400 people, aged between 24 and 65 (with an average age of 41.75) had a gender distribution of 59.7 per cent women and 40.3 per cent men. The final number of individuals for each type of category was 35 and, bearing in mind that the experiment covered four product categories, the total number of subjects for each assortment combination (this paper exclusively examines assortments offering PLs only) was 140. This paper focuses on the two scenarios composed exclusively of PLs (high and low value), and so the sample comprised a total of 280 individuals.

The experiment took into account four product categories: yogurt, sliced sandwich bread, detergent and toilet paper. The choice of these categories was made based on the classification carried out by Dhar et al. (2001) on the basis of the penetration/frequency relationship, which established four product categories:

(1) staples (high penetration/high frequency);

(2) niche products (low penetration/high frequency;

(3) variety enhancers (high penetration/low frequency); and

(4) fill-ins (low penetration/low frequency).

Selection of product categories and their inclusion in one of the four groups defined by Dhar et al. (2001), was carried out on the basis of a sample of 53 categories, which represented more than 60 per cent of sales of fast-moving consumer goods (FMCG) on the Spanish market.

Within each category, the brands submitted in the different scenarios were classified and selected based on their market share in Spain and the rating given to each brand by members of the IRI consumer panel, looking for those that were representative of the market. The same private label was used in all the categories. After analysis of a number of factors such as sales, PL awareness, the shelf space given over by the retailer and the number of stores, we selected the following PLs: Hacendado and Bosque Verde (Mercadona) and Auchan (Alcampo)[1].

Composite scales were used to measure the different variables of the proposed theoretical model, as they permit the assessment of psychological variables that are not directly observable (Churchill, 2003). Likert-type scales were used, which are widely used in the literature on assortment and brands.

After validating the measurement scales by means of exploratory factor analysis (EFA) of the available data and confirmatory factor analysis (CFA), the causal relationships (relationship hypotheses) of the proposed structural equation model were compared. To perform this analysis, the SPSS 18 statistics package was used, as was AMOS 16.

In accordance with the procedure and in line with Anderson and Gerbing (1988), we first carried out a joint confirmatory analysis of all the measurement scales using the structural equations methodology. Joint CFA of all the measurement scales of the proposed model gave satisfactory results. The goodness of fit of the confirmatory model showed a correct specification of the proposed factorial structure (Table I).

Table I.

Goodness of fit of structural model (single-brand assortments)

\begin{tabular}{cccccc}
\hline GFI & NFI & IFI & TLI & CFI & RMSA \\
\hline 0.901 & 0.910 & 0.948 & 0.937 & 0.947 & 0.056
\end{tabular}

Notes: GFI: goodness of fit index; NFI: normed fit index; IFI: incremental fit index; TLI: Tucker Lewis index; CFI: comparative fit index; RMSA: root mean square error of approximation 
Having assessed the reliability and validity of the model's scales using CFA, we proceeded to test the causal relationships of the structural model using the structural equations methodology. The structural equations modeling statistical technique was considered the most appropriate for analysis of the relationships identified in the proposed model. Once it was confirmed that the model had a good overall fit, we proceeded to observe the significance of the estimated parameters and thus assess the relevance of the initially specified causal relationships. The findings confirmed that the different indicators showed a good fit with the data model, with squared multiple correlation $\left(R^{2}\right)$ values of 0.076 (store image), 0.274 (private line purchase intention) and 0.21 (store switching intentions).

\section{Findings}

The findings obtained show significant and non-significant relationships between the model's variables. Table II contains the final results of the estimations of all the relationships.

Beginning with the significant relationships, the findings allow us to accept hypotheses $H 1, H 2, H 5, H 7, H 1 O$ and $H 11$. $H 1$ and $H 2$ have a direct relationship with store image. It is confirmed that the relationship between price consciousness and store image is consistent with the arguments made by the literature, to the effect that consumers concerned with price pay greater attention to this variable, focusing exclusively on paying as little as possible (Lichtenstein et al., 1993) or prioritizing it above other product attributes, which they consider superfluous. Also confirmed is the relationship between a favorable attitude toward PLs and store image. The literature endorses the positive relationship between a favorable attitude toward assortment and store image, with the attitude toward private brands being the subject of much research (Mihic and Culina, 2006; Pandaya and Joshi, 2012), with some papers focusing on the relationship between the perception of store image and attitude (Ajzen, 1988; Ajzen and Fishbein, 2004). This relationship is also supported by the work of Zielke and Dobbelstein (2007), who argue that attitudes toward PLs have, generally, a significant impact upon the image of and attitude toward a specific store.

The results obtained also support the existence of a relationship between a favorable attitude toward a PL and the intent to purchase this label. Generally speaking, the more favorable the attitude with regard to a behavior, the greater an individual's likelihood of carrying out said behavior (Ajzen, 1991). In this regard, the strategic aspect of brands as intangible assets creating value is clear. A number of papers confirm the positive

$\begin{array}{lc} & \\ \text { IMG_E } \leftarrow \text { CONC_P } & 0.111 \\ \text { IMG_E } \leftarrow \text { AT_PL } & 0.165 \\ \text { IMG_E } \leftarrow \text { P_VAR_ST } & \text { n.s. } \\ \text { INT_CP_PL } \leftarrow \text { IMP_CAT } & \text { n.s. } \\ \text { INT_CP_PL } \leftarrow \text { AT_PL } & 0.757 \\ \text { INT_CP_PL } \leftarrow \text { CONC_V } & \text { n.s. } \\ \text { INT_CP_PL } \leftarrow \text { IMG_E } & 0.224 \\ \text { INT_CB_E } \leftarrow \text { IMG_E } & \text { n.s. } \\ \text { INT_CB_E } \leftarrow \text { CONC_V } & \text { n.s. } \\ \text { INT_CB_E } \leftarrow \text { P_VAR_ST } & -0.325 \\ \text { INT_CB_E } \leftarrow \text { INT_CP_PL } & -0.226\end{array}$

Note: n.s. means not significant
Betting
exclusively by private labels

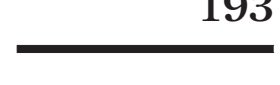


SJME

22,2

\section{4}

relationship between a favorable attitude toward PLs and the percentage of PL purchases (Burton et al., 1998; Garretson et al., 2002) or how a positive consumer rating of private brands translates into a greater propensity to purchase them (Sethuraman, 2006).

With regard to the variables associated with store switching intentions, the direct and inverse relationship with the perception of assortment variety and PL purchase intention is confirmed. In the former case, the literature holds that perception of a store's assortment variety affects the consumer's process of selecting it, in addition to finding a positive effect between the perception of a store's assortment variety and the intention of loyalty toward the latter (Hoch et al., 1999; Baker et al., 2002; Verhoef et al., 2007). Confirmation is also received of the direct and inverse relationship between PL purchase intention and store switching intentions. This is in line with papers such as that of Allen and Rao (2000), who argue that customer retention is the result of a number of factors, including perceived brand image and research such as that of Corstjens and Lal (2000), who state that the PL quality can give rise to differentiation between retailers and increase store loyalty. San Martín (2006) holds that, when a customer trusts a PL, he or she will also trust the store, thus lessening store switching intentions. These days, PLs help differentiate and position a store image, and this is consistent with research such as that of Bigné et al. (2013), whose findings show that a favorable image of PLs helps build a more solid store image, which impacts upon creation of the latter's value.

Table III shows all the parameters of the significant relationships, while Figure 2 provides a summary of the different relationships, as well as the values of the estimations.

Table III.

Final results (significant relationships)

\begin{tabular}{llcccc}
\hline Hypothesis & & Estimate & SE & CR & P \\
\hline (H1) & IMG_E $\leftarrow$ CONC_P & 0.111 & 0.054 & 2.047 & 0.041 \\
(H2) & IMG_E $\leftarrow$ AT_PL & 0.165 & 0.058 & 2.833 & 0.005 \\
(H5) & INT_CP_PL $\leftarrow$ AT_PL & 0.757 & 0.099 & 7.619 & $* * *$ \\
(H7) & INT_CP_PL $\leftarrow$ IMG_E & 0.224 & 0.112 & 1.997 & 0.046 \\
(H10) & INT_CB_E $\leftarrow$ P_VAR_ST & -0.325 & 0.071 & -4.596 & $* * *$ \\
(H11) & INT_CB_E $\leftarrow$ INT_CP_PL & -0.226 & 0.051 & -4.44 & $* * *$
\end{tabular}

Notes: SE: standard error; CR: critical ratio

Figure 2.

Final model of relationships

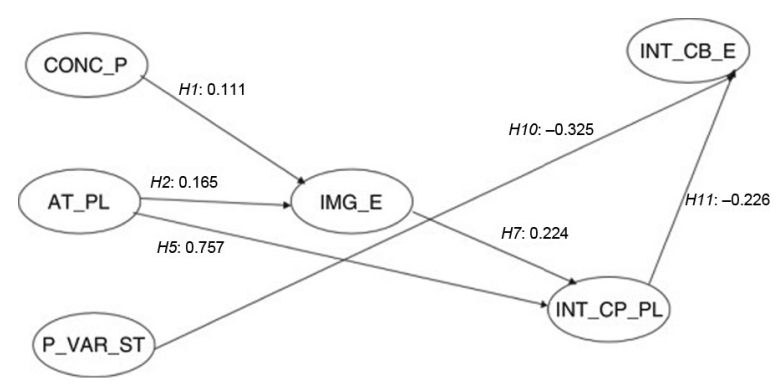

Notes: CONC_P: price consciousness; AT_PL: attitude toward PLs; $\mathrm{P}_{-}$VAR_ST: assortment variety perception; IMAG_E: store image; INT_CB_E: store switching intentions; INT_CP_PL: PL purchase intentions 
Additionally, we found five non-significant relationships, meaning we could not accept hypotheses $\mathrm{H3}, \mathrm{H} 4, \mathrm{H} 6, \mathrm{H} 8$ and $\mathrm{H} 9$. With regard to the relationship between assortment variety and store image, although the literature argues that wider assortments tend to be perceived more favorably by consumers, there is really no consensus on this issue, as both large and small assortments have their pros and cons (Briesch et al., 2009; Chernev and Hamilton, 2009). In this work, we have found that the relationship is not significant in PL-only assortments, as the perception of assortment variety is related to the degree of differentiation of the different product variables with regard to their key elements, (Hoch et al., 2002; Van Herpen and Pieters, 2002): in the case of single-brand assortments, this does not occur.

Also, not borne out is the hypothesis associating product category involvement and PL purchase intention. Although the literature argues that the degree of consumer engagement with the product influences the decision to purchase PLs, the relationship is not clear, given the conflicting results obtained (Miquel et al., 2002; Berkowitz et al., 2005). It appears that the level of consumer engagement can vary depending upon the different product categories. Along the same lines is the work by Zaichkowsky (1985), who states that, in general, consumers show a higher level of engagement with durable than with non-durable products. Nor do the findings obtained allow one to argue for the relationship between value consciousness and PL purchase intention when dealing with assortments featuring an own brand only. Several authors (Jin and Suh, 2005) argue for the existence of a positive direct effect between value consciousness and PL purchase intention. Nevertheless, we can see that this does not occur with single brand (PL) assortments. We believe that consumers highly focused on obtaining the best value in their purchases wish to have more information to hand and be able to compare between different options and decide upon the information obtained. Because of all this, they feel more comfortable in stores where they can select products from amongst numerous alternatives.

As far as store switching intention is concerned, the findings do not allow us to accept the direct and negative relationship proposed with the positive store image. A number of authors (Sirgy and Coskun, 1985; Wu et al., 2011) argue that a store image is considered an important background factor to loyalty to it, in that it favors repeat purchases and lessens store switching intentions. However, our findings indicate that, in assortments comprising solely PLs, said relationship is not significant. This may be associated with the fact that hard discount store and category killer customers could be more loyal to a specific kind of purchasing behavior (the search for low prices, mainly via PLs) than to the store itself, which may lead them to store switching if they perceive better conditions elsewhere. The proposed relationship between value consciousness and store switching intentions is also not significant. The literature suggests the existence of a positive influence of perceived value on store loyalty (Chen and Quester, 2006). In this regard, Gómez et al. (2011) confirm that value consciousness plays a key role in the formation of loyalty, especially in the case of large buyers. Nevertheless, consumers concerned with value are also aware that the search for information and for price comparisons, as well as the diversity of purchasing in general, entail an investment in time and opportunity costs. We therefore consider that consumers' value consciousness lessens their store switching intentions, provided that it offers wide assortments and presents offerings perceived by the buyer as contributing value.

\section{Conclusions and implications for retail management}

Below, we set out the conclusions obtained and propose a number of recommendations, in terms of management implications, for retailers opting for assortments comprised 
exclusively of PLs, be this owing to strategic reasons or budgetary restrictions. We feel these conclusions and recommendations are appropriate in line of the three result variables analyzed:

(1) The image of stores only offering their own brands is mainly configured on the basis of price consciousness and attitudes toward PLs. Therefore, offering an assortment with price-competitive PLs is key to the strategy of differentiating them from other retailers. The current context of economic recession would appear to have accentuated purchasing processes based on obtaining low prices, which has led to considerable enhancement of the image of those establishments able to react and adapt to the new times. We can observe the development of numerous image campaigns focused on very competitive prices, allowing these retailers to position themselves as the consumers' allies at times of particular economic difficulties. In this same regard, the fact that many consumers regard PLs as real alternatives and as offering quality similar to national brands has led to the securing of a better image not only for the PLs themselves but also for the retailers opting for them. When the consumers have a good attitude toward PLs, retailers positioning themselves as hard discount stores, characterized by a very restricted assortment, may see their image bolstered if they promote a sales strategy based on low prices and display a firm commitment to their own brands. This fact is important in the sense that, if consumers have a favorable attitude toward a PL and find the product to satisfy their needs in the store, they do not need wider assortments, and they may even have a better perception if the assortment comprised exclusively PLs as, for them, the positive rating is even greater when they can find their preferred option (the PL, in this case) on the shelves, above and beyond other considerations regarding assortment size. Retailers need to know the extent to which their customers demand greater variety, in addition to knowing in which kinds or categories of products.

(2) The private label purchase intention on the part of consumers is, at the same time, greatly influenced by the image of the store itself and by a favorable attitude toward PLs. It is reasonable to assume that, if retailers have a favorable image, customers transfer this brand value to their PLs and trust them. It is clear that consumer attitudes toward PLs have changed substantially in recent years, allowing them to compete directly with national brands. This is because, amongst other factors, consumers have reduced their brand consciousness in favor of greater price and value consciousness. A change has occurred in the consciousness of consumers, who see themselves as rational and intelligent individuals in their purchasing processes, seeking the best value for money. This has led to the appearance of a new kind of consumer who now seeks not only lower prices in PLs but also a degree of quality. This can be appreciated more clearly in the case of customers of retailers whose assortments are made up exclusively of PLs, who are very aware that they seek keenly priced products that allow them to save time and money while purchasing. Private label customers of establishments such as hard discount stores, with assortments made up exclusively of PLs, display a high level of loyalty toward said brands. This being the case, PLs constitute a tool for creating loyalty for these retailers, as their customers can only buy them at their stores. Nevertheless, when consumers have a high degree of engagement with a particular product category, even if they have the intention to purchase PLs, they are more comfortable in stores where they can compare between different products. 
(3) Customer loyalty strategies on the part of retailers only featuring own brands in their assortments should be aimed at ensuring that consumers clearly perceive that their assortment provides real value and that, although it is limited in terms of number of brands and alternatives, it can meet all their needs. Price consciousness and value consciousness are therefore configured as factors that are more important than store loyalty itself. Customers of this kind of store do not consider switching retailer when they perceive that the assortment meets their requirements, as they are aware of the costs involved in the process of searching for alternatives. Additionally, PLs are nowadays regarded as a smart purchase option. Therefore, retailers of this kind must develop strategies that allow them to prioritize their PLs, this helps them improve their image, provided that this gives value to their customers and which furthermore offers them better sales margins. Some PLs are so deeply rooted in society that they are perceived as if they were another national brand, with a different positioning and aimed at different segments of consumers. Those such as Aliada, SeleQtia and Hacendado (the own brands of Hipercor, Eroski and Mercadona, respectively) have their own image amongst consumers, many of whom visit the retailers' stores specifically in search of these brands. The success of Mercadona's strategy in terms of image is well known, with its clear commitment to assortments made up of its PLs. Mercadona's positioning is that of a retailer making quality brands, with the additional peculiarity that, if consumers wish to buy said brands, they must necessarily do so in this supermarket chain's stores. This has been achieved, above all, by means of a good brand creation strategy.

\section{Limitations and future lines of research}

As is only logical, this work is not free from some limitations, most of which can provide the jumping off point for future lines of research. Firstly, our research has been limited in scope to Spain. Given the special circumstances of this market, where the economic crisis has been particularly intense and where the market share of PLs is well above the world average, it would be interesting to replicate the experiment in other geographical areas to test whether the relationships and models developed can be confirmed or not. Secondly, an experimental approach has been used to obtain the data, with all the limitations inherent in this type of research, in that it is based on a representation of real situations, without actually being "real". Thirdly, another possible limitation comes as a consequence of the way in which store image has been measured. Although we have used a scale validated in the literature, store image is a multidimensional construct affected by many variables, some of which have not been taken into account in this research (e.g. physical environment, shelving/display implementation and sales promotions), due, amongst other reasons, to the methodology used. Therefore, the way in which image has been measured provides a simplification of the real image. Fourthly, although the sample is representative of Spanish consumers, we have found different socioeconomic circumstances amongst them. In future research, it would be worth understanding what consumer behavior is like in different segmentations, to analyze whether there are significant differences between profiles or groups. Finally, not all brands have the same value for consumers, with the existence of the concept of high and low value. It would be interesting to tackle this point in future research to try to understand how brand value impacts upon consumer behavior. 


\section{Note}

1. Further details on the PL selection process can be provided on request from the paper's corresponding author.

\section{References}

Agarwal, S. and Teas, R.K. (2001), "Perceived value: mediating role of perceived risk", Journal of Marketing Theory and Practice, Vol. 9 No. 4, pp. 1-14.

Ailawadi, K.L. and Harlam, B. (2004), "An empirical analysis of the determinants of retail margins: the role of store-Brand share", Journal of Marketing, Vol. 68 No. 1, pp. 147-165.

Ailawadi, K., Pauwels, K. and Steenkamp, J.B. (2008), "Private label use and store loyalty”, Journal of Marketing, Vol. 72 No. 6, pp. 19-30.

Ailawadi, K.L., Neslin, S. and Gedenk, K. (2001), "Pursuing the value conscious consumer: store brands versus national Brand promotions", Journal of Marketing, Vol. 65 No. 1, pp. 71-89.

Ajzen, I. (1988), Attitudes, Personality, and Behavior, Open University Press, Dorsey Press, MiltonKeynes, Chicago, IL.

Ajzen, I. (1991), "The theory of planned behaviour", Organizational Behavior and Human Decision Processes, Vol. 50 No. 2, pp. 179-211.

Ajzen, I. and Fishbein, M. (2004), "Questions raised by a reasoned action approach: reply to ogden (2003)”, Health Psychology, Vol. 23 No. 4, pp. 431-434.

Allen, D. and Rao, T. (2000), Analysis of Customer Satisfaction Data, ASQ Quality Press, Milwaukee, WI.

Alliance Consulting Group (2014), "The threat of retailer brands. how national brand manufacturers can protect their brands and profits", available at: www.alliancecg.com/uploads/ the_threat_of_retailer_brands.pdf

Anderson, J.C. and Gerbing, D.W. (1988), "Structural equation modeling in practice: a review and recommended two-step approach", Psychological Bulletin, Vol. 103 No. 3, pp. 411-423.

Arnold, S.J., Ma, S. and Tigert, D.J. (1978), "A comparative analysis of determinant attributes in retail store selection”, Advances in Consumer Research, Vol. 5 No. 1, pp. 663-667.

Baker, J., Parasuraman, A., Grewal, D. and Voss, G.B. (2002), "The influence of multiple store environment cues on perceived merchandise value and patronage intentions", Journal of Marketing, Vol. 66 No. 2, pp. 120-141.

Bauer, J.C., Kotouc, A.J. and Rudolph, T. (2012), "What constitutes a 'good assortment'? a scale for measuring consumers' perceptions of an assortment offered in a grocery category", Journal of Retailing and Consumer Services, Vol. 19 No. 1, pp. 11-26.

Berg, N. and Queck, M. (2010), Private Labels: The Brands of the Future, Planet retail.

Berkowitz, D., Bao, Y. and Allaway, A.W. (2005), "Hispanic consumers, store loyalty and Brand preference", Journal of Targeting, Measurement and Analysis for Marketing, Vol. 14 No. 1, pp. 9-24.

Berné, C. (2006), "Análisis de la demanda de servicios de distribución minoristas", Información Comercial Española (ICE), Vol. 828, pp. 83-98.

Bigné, E., Borredá, A. and Miquel, M.J. (2013), "El valor del establecimiento y su relación con la imagen de marca privada: efecto moderador del conocimiento de la marca privada como oferta propia del establecimiento", Revista Europea De Dirección y Economía De La Empresa, Vol. 22 No. 1, pp. 1-10.

Briesch, R.A., Chintagunta, P.K. and Fox, E.J. (2009), "How does assortment affect grocery store choice?”, Journal of Marketing Research, Vol. 46 No. 2, pp. 176-189.

Broniarczyk, S.M., Hoyer, W.D. and McAlister, L. (1998), "Consumers' perceptions of the assortment offered in a grocery category: the impact of item reduction", Journal of Marketing Research, Vol. 35 No. 2, pp. 166-176. 
Burton, S., Lichtenstein, D.R., Netemeyer, R.G. and Garretson, J.A. (1998), "A scale for measuring attitude toward private label products and an examination of its psychological and behavioral correlates", Journal of the Academy of Marketing Science, Vol. 26 No. 4, pp. 293-306.

Casares, J. and Rebollo, A. (1996), Distribución Comercial, Civitas, Madrid.

Castelló, A. (2012), "La batalla entre marca de distribuidor y marca de fabricante en el terreno publicitario", Pensar La Publicidad, Vol. 6 No. 2, pp. 381-405.

Chakravarti, A. and Janiszewski, C. (2003), "The influence of macro-level motives on consideration set composition in novel purchase situations", Journal of Consumer Research, Vol. 30 No. 2, pp. 244-258.

Chen, S.C. and Quester, P.G. (2006), "Modeling store loyalty: perceived value in market orientation practice", Journal of Services Marketing, Vol. 20 No. 3, pp. 188-198.

Chernev, A. (2003), "When more is less and less is more: the role of ideal point availability and assortment in consumer choice", Journal of Consumer Research, Vol. 30 No. 2, pp. 170-183.

Chernev, A. and Hamilton, R. (2009), "Assortment size and option attractiveness in consumer choice among retailers", Journal of Marketing Research, Vol. 46 No. 3, pp. 410-420.

Churchill, G.A. (2003), Investigación De Mercados, 4th ed., Ciudad de México, Thomson.

Corstjens, M. and Lal, R. (2000), "Building store loyalty through store brands", Journal of Marketing Research, Vol. 37 No. 3, pp. 281-292.

Cruz, I. (1999), Los Canales De Distribución De Productos De Gran Consumo: concentración y Competencia, Editorial Pirámide.

Darwar, N. and Parker, P. (1994), "Marketing universals: consumer use of brand name, price, physical appearance and retailing in United Kingdom", Journal of Marketing, Vol. 58 No. 2, pp. 81-95.

De Wulf, K., Odekerken-Schröder, G. and Iacobucci, D. (2001), "Investments in consumer relationships: a cross-country and cross-industry exploration", Journal of Marketing, Vol. 65 No. 4, pp. 33-50.

Dhar, S., Hoch, S.J. and Kumar, N. (2001), "Effective category management depends on the role of the category", Journal of Retailing, Vol. 77 No. 2, pp. 165-184.

Dick, A. and Basu, K. (1994), "Customer loyalty: toward an integrated conceptual framework", Journal of the Academy of Marketing Science, Vol. 22 No. 2, pp. 99-114.

Fernández, A. (2010), "La situación actual de las marcas de distribuidor desde la perspectiva de los fabricantes: un estudio cualitativo", Distribución y Consumo, No. 24, pp. 24-35.

Fernández, R. and Reinares, P. (1998), “Aspectos teóricos y estratégicos en la gestión de las marcas de distribuidor”, Distribución y Consumo, Vol. 38, pp. 92-101.

Finn, A. and Louviere, J.J. (1996), "Shopping center image, consideration, and choice: anchor store contribution", Journal of Business Research, Vol. 35 No. 3, pp. 241-251.

Galván, P. (2007), "Merchandising de las marcas de distribuidor vs marcas de fabricante", Esic-Market, Vol. 126, pp. 247-270.

Garretson, J.A., Fisher, D. and Burton, S. (2002), "Antecedents of private label attitude and national Brand promotion attitude: similarities and differences”, Journal of Retailing, Vol. 78 No. 2, pp. 91-99.

Gázquez-Abad, J.C., Martínez-López, F.J., Mondéjar-Jiménez, J.A. and Esteban-Millat, I. (2015), "Mixed assortments vs. store Brand-only assortments: the impact of assortment composition and consumer characteristics on store loyalty", Revista Española De Investigación En Marketing, ESIC, Vol. 19, pp. 24-45.

Gómez, M. and Okazaki, S. (2007), "Estimating store Brand shelf space: a new framework using neural networks and partial least squares", International Journal of Market Research, Vol. 51 No. 2, pp. 243-266.

Gómez, M., Oubiña, J. and Rubio, N. (2011), “Antecedentes de la lealtad a las marcas de distribuidor: diferencias entre grandes y pequeños compradores", Colección De Documentos De Trabajo Cátedra Fundación Ramón Areces De Distribución Comercial, pp. 1-28. DOCFRADIS 05/2011. 
González-Benito, O. and Martos-Partal, M. (2010), "Marcas de distribuidor y fidelización de clientes”. en distribución comercial y comportamiento del consumidor", Cátedra Fundación Ramón Areces De Distribución Comercial, pp. 85-100.

Henderson, T.A. and Mihas, E.A. (2000), "Building retail brands", The McKinsey Quarterly, Vol. 3, pp. 110-117.

Hoch, S., Bradlow, E.T. and Wansink, B. (1999), "The variety of an assortment", Marketing Science, Vol. 18 No. 4, pp. 527-546.

Hoch, S.J., Bradlow, E.T. and Wansink, B. (2002), "Rejoinder to the variety of an assortment”, Marketing Science, Vol. 21 No. 3, pp. 342-346.

Hu, F. and Chuang, C.C. (2009), "How can different Brand strategies lead to retailers' success? comparing manufacturers Brand for coca-cola and private brand for costco", Journal of Global Business Issues, Vol. 3 No. 1, pp. 129-135.

IRI (2015), "Private label in western economies", IRI Private Label Special Report, available at: www. iriworldwide.com/IRI/media/IRI-Clients/PrivateLabel_report_final_7Jan15.pdf

Jin, B. and Suh, Y.G. (2005), "Integrating effect of consumer perception factors in predicting private brand purchase in a Korean discount store context", Journal of Consumer Marketing, Vol. 22 No. 2, pp. 62-71.

Johnson, M.D., Gustafsson, A. and Andreassen, T.W. (2001), "The evolution and future of national customer satisfaction index models", Journal of Economic Psychology, Vol. 22 No. 2, pp. 217-245.

Kantar Worldpanel (2016), available at: www.kantarworldpanel.com/es/grocery-market-share/spain

Kelmeci-Schneider, G. (2004), Handelsmarken Im Interkulturellen Vergleich: Einstellungen in Deutschland Und in Der Türkei Am Bispiel Des LEH, Handelsforschung, BBE, Cologne, pp. 249-266.

Kumar, N. and Steenkamp, J.E.M. (2007), Private Label Strategy: How to Meet the Store Brand Challenge, Harvard University Press, Cambridge MA.

Lamey, L., Deleersnyder, B., Dekimpe, M.G. and Steenkamp, J.B. (2007), "How business cycles contribute to private-label success: evidence from the United States and Europe", Journal of Marketing, Vol. 71 No. 1, pp. 1-15.

Lamey, L., Deleersnyder, B., Steenkamp, J.-B. and Dekimpe, M. (2012), "The effect of business-cycle fluctuations on private-label share: what has marketing conduct got to do with it?", Journal of Marketing, Vol. 76, pp. 1-19.

Lichtenstein, D., Netemeyer, R. and Ridgway, N. (1990), "Distinguishing coupon proneness from value consciousness: an acquisition-transaction utility theory perspective", Journal of Marketing, Vol. 54 No. 3, pp. 54-67.

Lichtenstein, D., Ridgway, N. and Netemeyer, R. (1993), "Price perceptions and consumer shopping behavior: a field study", Journal of Marketing Research, Vol. 30 No. 2, pp. 234-245.

Liljander, V., Polsa, P. and Van Riel, A. (2009), "Modelling consumer responses to an apparel store Brand: store image as a risk reducer", Journal of Retailing and Consumer Services, Vol. 16 No. 4, pp. 281-290.

Manzur, E., Olavarrieta, S., Hidalgo, P., Farías, P. and Uribe, R. (2011), "Store Brand and national Brand promotion attitudes antecedents", Journal of Business Research, Vol. 64 No. 3, pp. 286-291.

Martenson, R. (2007), "Corporate brands image, satisfaction and store loyalty: a study of the store as a Brand, store brands and manufacturer brands", International Journal of Retail \& Distribution Management, Vol. 35 No. 7, pp. 544-555.

Martineau, P. (1958), “The personality of the retail store”, Harvard Business Review, Vol. 36, pp. 47-55.

Martínez, E. and Montaner, T. (2008), "Characterization of Spanish store brand consumers", International Journal of Retail \& Distribution Management, Vol. 36 No. 6, pp. 477-493.

McDougall, G.H.G. and Levesque, T. (2000), "Customer satisfaction with services: putting perceived value into the equation", Journal of Services Marketing, Vol. 14 No. 5, pp. 392-410. 
Méndez, J.L., Oubiña, J. and Rubio, N. (2008), "Expert quality evaluation and price of store vs. manufacturer brands: an analysis of the Spanish mass market", Journal of Retailing and Consumer Services, Vol. 15 No. 3, pp. 144-155.

Mihic, M. and Čulina, G. (2006), "Buying behavior and consumption: social class versus income", Management, Vol. 11 No. 2, pp. 77-92.

Miquel, S., Caplliure, E.M. and Aldas-Manzano, J. (2002), "The effect of personal involvement on the decision to buy store brands", Journal of Product \& Brand Management, Vol. 11 No. 1, pp. 6-18.

Miranda, M.J. and Joshi, M. (2003), "Australian retailers need to engage with private labels to achieve competitive difference", Asia Pacific Journal of Marketing and Logistics, Vol. 15 No. 3, pp. 34-47.

North, E.J., De Vos, R.B. and Kotze, T. (2003), "The importance of apparel product attributes for the female buyers", Journal of Family Ecology and Consumer Science, Vol. 31, pp. 41-51.

Oliver, R.L. (1999), “Whence customer loyalty?”, Journal of Marketing, Vol. 63, pp. 33-44.

Oubiña, J., Rubio, N. and Yagüe, M.J. (2006), "Strategic management of store brands: an analysis from the manufacturer's perspective", International Journal of Retail \& Distribution Management, Vol. 34 No. 10, pp. 742-760.

Paiva, G., Sandoval, M. and Bernardin, M. (2012), "Factores explicativos de la lealtad de clientes de los supermercados", Innovar, Vol. 22 No. 44, pp. 153-164.

Pandaya, A.R. and Joshi, M.A. (2012), "A study on consumers" attitude towards private labels: a special focus in Baroda \& Rajkot”, International Journal of Business and Management Tomorrow, Vol. 2 No. 5.

Pappu, R. and Quester, P. (2006), "Does customer satisfaction lead to improved brand equity? An empirical examination of two categories of retail brands", Journal of Product \& Brand Management, Vol. 15 No. 1, pp. 4-14.

Pepe, M.S., Abratt, R. and Dion, P. (2012), "Competitive advantage, private-label brands and category profitability", Journal of Marketing Management, Vol. 28 Nos 1/2, pp. 154-172.

Puelles, J.A. and Puelles, M. (2003), "Marcas de distribuidor: más de 30 años de un proceso dinámico, competitivo e imparable", Distribución y Consumo, Vol. 69, pp. 55-71.

Richardson, P., Dick, A. and Jain, A. (1994), "Extrinsic and intrinsic cue effects on perceptions of store Brand quality", Journal of Marketing, Vol. 58 No. 4, pp. 28-36.

Rondán, F.J., Navarro, A. and Phau, I. (2006), "The influence of price and Brand loyalty on store brands versus national brands", The International Review of Retail, Distribution and Consumer Research, Vol. 16 No. 4, pp. 433-452.

San Martín, S. (2006), "A model of consumer relationships with store brands, personnel and stores in Spain”, International Review of Retail, Distribution and Consumer Research, Vol. 16 No. 4, pp. $453-469$.

Semeijin, J., Van Riel, A.C.R. and Ambrosini, A.B. (2004), "Consumer evaluations of store brands: effects of store image and product attributes", Journal of Retailing and Consumer Services, Vol. 11 No. 4, pp. 247-258.

Serra, T. and Puelles, J.A. (1993), "Análisis de las marcas de distribución en el mercado de la alimentación", Actas de los V encuentros de Profesores Universitarios de Marketing, Sevilla, pp. 103-108.

Sethuraman, R. (2006), "Private-label marketing strategies in packaged goods: management beliefs and research insights", Marketing Science Institute Working Paper, pp. 27-44.

Simonson, I. (1999), "The effect of product assortment on buyer preferences", Journal of Retailing, Vol. 75 No. 3, pp. 347-370.

Sirgy, J. and Coskun, A. (1985), "A path analytic model of store loyalty involving self-concept, store image, geographic loyalty, and socioeconomic status", Journal of the Academy of Marketing Science, Vol. 13 No. 3, pp. 265-292. 
SJME

22,2

Sirohi, N., McLaughlin, E.W. and Wittink, D.R. (1998), "A model of consumer perceptions and store loyalty intentions for a supermarket retailer", Journal of Retailing, Vol. 74 No. 2, pp. 223-245.

Siti, N.J., Pan, E.L. and Mohaini, M. (2012), “Consumers' perceptions, attitudes and purchase intention towards private label food products in Malaysia", Asian Journal of Business and Management Sciences, Vol. 2 No. 8, pp. 73-90.

Sloot, L.M. and Verhoef, P.C. (2008), "The impact of brand delisting on brand switching and store switching intentions", Journal of Retailing, Vol. 84 No. 3, pp. 281-296.

Sloot, L.M. and Verhoef, P.C. (2011), "Reducing assortments without losing business, key lessons for retailers and manufacturers", New Strategies, Vol. 3 No. 2, pp. 27-33.

Van Herpen, E. and Pieters, R. (2002), "The variety of an assortment: an extension to the attribute-based approach", Marketing Science, Vol. 21 No. 3, pp. 331-341.

Vázquez, R. and Trespalacios, J.A. (2006), Estrategias De Distribución Comercial: Diseño Del Canal De Distribución y Relación Entre Fabricantes y Detallistas, Thompson, Madrid.

Verhoef, P., Langerak, F. and Donkers, B. (2007), "Understanding brand and dealer retention in the new car market: the moderating role of Brand tier", Journal of Retailing, Vol. 83 No. 1, pp. 97-113.

White, C. and Hoffrage, U. (2009), "Testing the tyranny of too much choice against the allure of more choice", Psychology \& Marketing, Vol. 26 No. 3, pp. 280-298.

Wiebach, N. and Hildebrandt, L. (2002), "Explaining customers' switching patterns to Brand delisting", Journal of Retailing and Consumer Services, Vol. 19 No. 1, pp. 1-10.

Wu, P.C., Yeh, G.Y. and Hsiao, C.R. (2011), "The effect of store image and service quality on brand image and purchase intention for private label brands", Australasian Marketing Journal, Vol. 19 No. 1, pp. 30-39.

Zaichkowsky, J.L. (1985), "Measuring the involvement construct", Journal of Consumer Research, Vol. 12 No. 3, pp. 341-352.

Zielke, S. and Dobbelstein, T. (2007), “Customers' willingness to purchase new store brands”, Journal of Product \& Brand Management, Vol. 16 No. 2, pp. 112-121.

\section{Corresponding author}

José Luis Ruiz-Real can be contacted at: jrr672@ual.es

For instructions on how to order reprints of this article, please visit our website: 